\title{
The $\mathrm{JO}$

VoL. $\mathrm{x}$, NO. 2

APRIL

Navigation and Traffic Control over the North Atlantic 115 D. O. Fraser

Since when have we known that the Earth is a Globe ?

E. G. R. TAYLOR

Port Operation in Fog

W. R. Colbeck, L. S. Le Page and R. F. hansford

Off the Beaten Track

A Lecture for Cadets

All-weather Helicopter Operation

P. A. Hearne

Relative Movement and the Collision Problem

E. W. Anderson, F. J. Wylie, H. Topley, E. M. Robb, D. H. Sadler and G. A. A. Grant

\section{FORUM}

The Place of Navigation in Modern Air Transport

The 'Box' or Pocket Sextant

Modern Nautical Tables

The Region of Collision

Reviews

Letter to the Editor

THE INSTITUTE OF NAVIGATION

AT THE ROYAL GEOGRAPHICAL SOCIETY I KENSINGTON GORE LONDON SW 7

JOHN MURRAY (PUBLISHERS) LTD., 50 ALBEMARLE STREET, LONDON wı 


\section{THE INSTITUTE OF NAVIGATION}

\section{Patron}

H.R.H. THE DUKE OF EDINBURGH, K.G., к.T.

OFFICERS AND COUNCIL

President

Captain A. M. A. Majendie

Vice-Presidents

Rear-Admiral K. St. B. Collins, C.в.E.

Dr. G. E. R. Deacon, C.B.E., F.R.s.

Hon. Treasurer: Mr. D. O. Fraser

Chairman of the Technical Committee

Wing Commander E. W. Anderson, O.B.E., D.F.C., A.F.C.

Chairman of the Membership and Fellowship Committee

Captain R. W. Ravenhill, C.B.E., D.s.C., R.N.(ret.).

Other Members of the Council

Captain W. Baillie, M.v.o., O.B.E.

Mr. C. S. Durst, O.B.E.

Mr. W. L. S. Harrison

Mr. J. B. Parker

Group Capt. D. C. McKinley, D.F.C., A.F.C.

Captain G. C. Saul

Captain H. Topley

The directors of navigation at the Admiralty, the Air Ministry and the Ministry of Transport and Civil Aviation are invited to attend meetings of the Council as ex-officio members.

Executive Secretary: M. W. Richey. Assistant Secretary : Miss L. M. A. Tower

\section{The Journal of the Institute of Navigation}

THE Journal is published quarterly by the Institute and is edited by the Executive Secretary. It contains original papers contributing to the science of navigation, including those presented at meetings of the Institute together with the ensuing discussion. In addition the Journal includes a record of current navigational work, reviews of important books, and other matters of concern to those Interested in navigation. The views expressed in the Journal are not necessarily those of the Institute, or of any organization or department to which the authors may belong.

The Journal is free to all members of the Institute. It is sold to the public at ten shillings per copy or, by subscription, at forty-one shillings per annum (post free) and may be obtained through all booksellers and John Murray (Publishers) Ltd., 50 Albemarle Street, London WI.

Contributions, which are welcomed from both members and non-members, should be addressed to the Editor.

Enquiries for advertising space should be addressed to the Institute offices.

The postal address of the Institute is:

The Institute of Navigation, at The Royal Geographical Society,

I Kensington Gore, London SW7.

Telephone: Kensington $502 x$. 


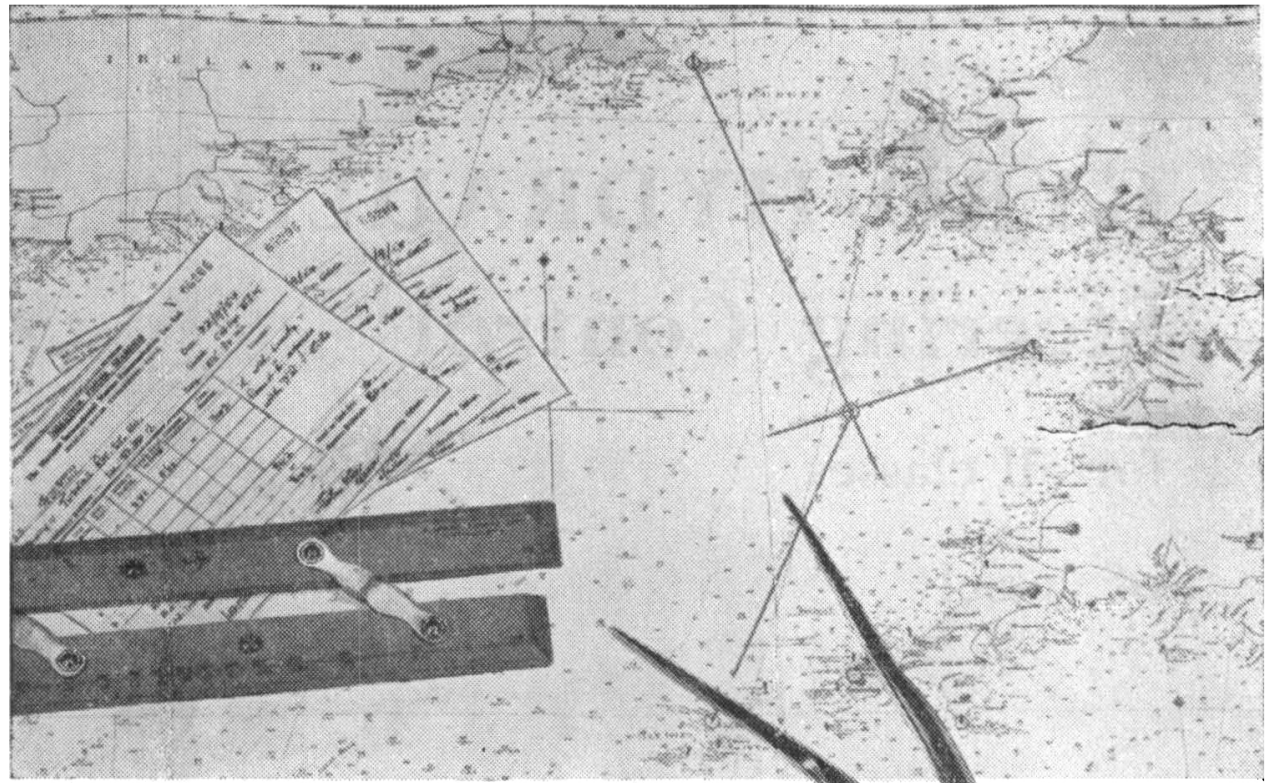

Reproduced from $A d$ miralty wichart No.
1598 with the per-

\section{UTTERLY RELIABLE}

mission of the Controller. H.M. Stalioniry Office and of the Hydrographir of the
Naw.

\section{D.F. BEARINGS}

\section{when you need them most}

When prolonged bad weather has made it impossible to obtain sights during an ocean passage and the navigator is approaching crowded shipping lanes and a dangerous coast he turns with confidence to his Marconi "Lodestone". He knows it will give him the accurate trustworthy information he needs to enable him to proceed in safety-in foul weather, when the ship is lively, just as in fair.

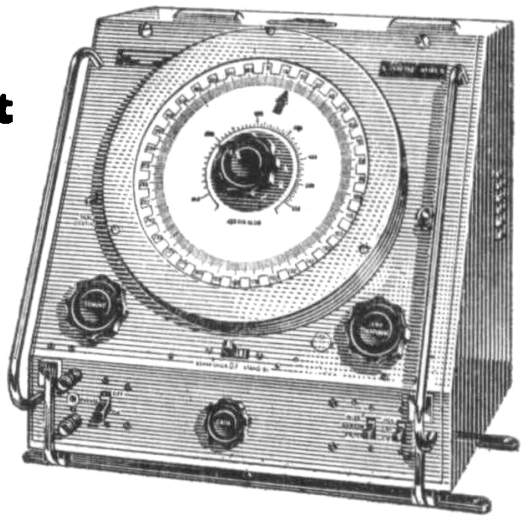

\section{Marconi "Lodestone" Direction-Finder}

The "Lodestone" is sturdy and compact, arranged for desk or bench mounting and may be installed at any distance up to 60 ft. from the loop aerial. Gyro-compass coupling is available if required. Degree and tuning scales are of large diameter and internally illuminated for precision and easy reading. The use of the "sense check" switch automatically changes the bearing scale to the correct setting. Only in very exceptional cases will correction curves be necessary

\section{MARCONI MARINE}

\section{maintain service facilities in all principal ports}

THE MARCONI INTERNATIONAL MARINE COMMUNICATION COMPANY LIMITED

Marconi House, Strand, London, W.C.2. Telephone : COVent Garden 1234 


\section{GYRO-HYDRAULIC}

\section{Steering Control}

\section{for all classes \\ of $\dot{\text { vessel }}$}

All the advantages of the Sperry Gyropilot and the hydraulic telemotor from a single control unit in the wheelhouse

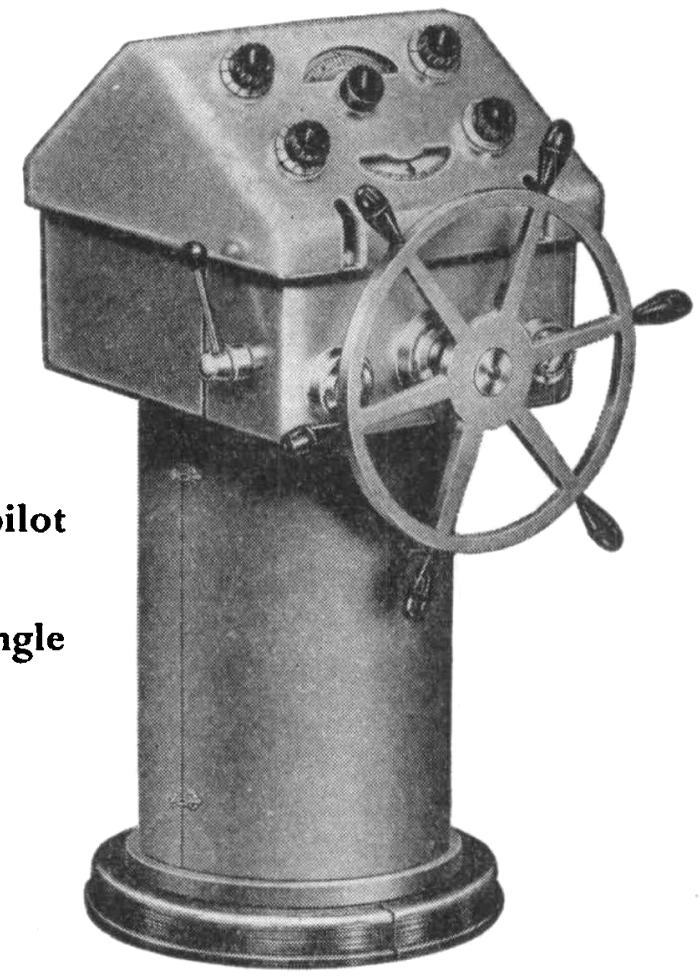

The bridge unit illustrated here provides for three separate steering control systems :

- Hand-hydraulic telemotor

- Hand-electric telemotor

- Automatic steering by Gyro when installed in conjunction with a gyro compass system

\section{S P E R R Y}

^ Full information will gladly be supplied on request

SPERRY GYROSCOPE COMPANY LIMITED - GREAT WEST RD. - BRENTFORD · MIDDX Telephone: EALing 6771 


\section{WITH 900 PASSENGERS ON BOARD}

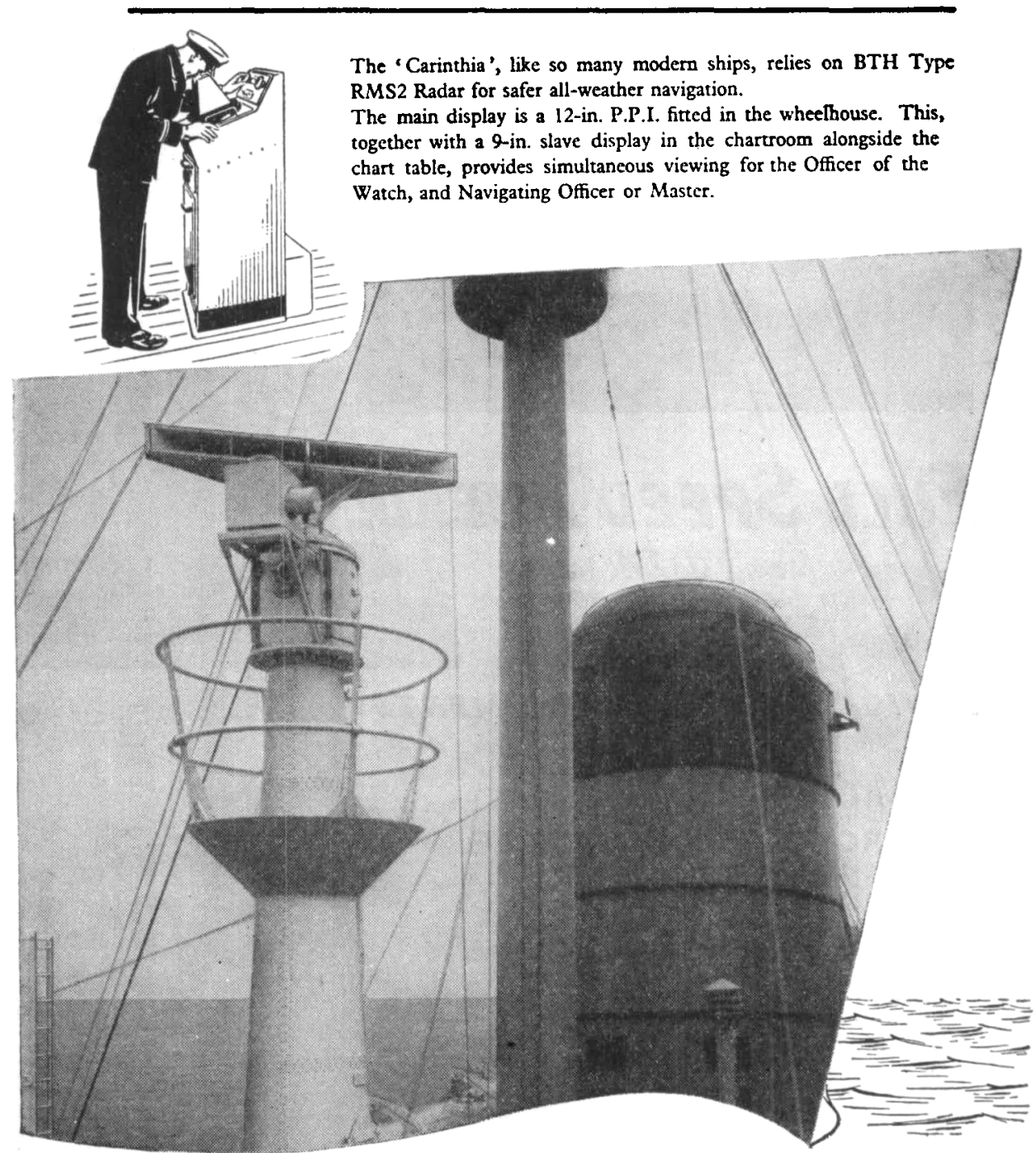

The 20,000-ten' Carinthia' was built by John Brown, Clydebank, and commissioned for Cunard Steam-Ship Co. Lid. in 1956. 'Saxonia' and 'Ivernia', two sister ships already in service, are also fitted with BTH Type RMS2 Radar. 


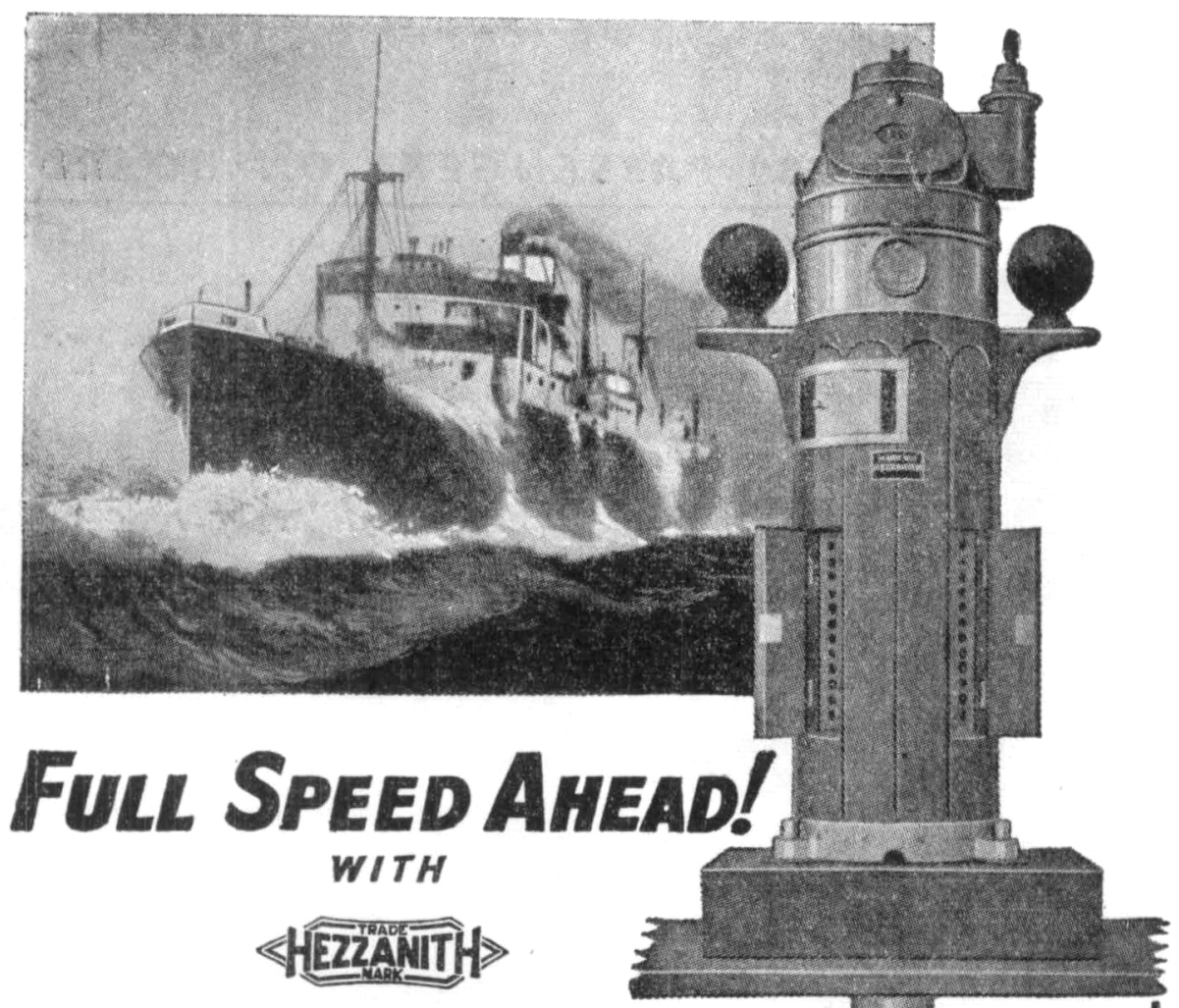

NAVIGATIONAL INSTRUMENTS

\section{The " HEZZANITH" Patent MARK VII PROJECTOR BINNACLE AND COMPASS}

By means of o series of optical elements an enlarged erect image of a portion of the card covering an ore of $40^{\circ}$ in length is produced on a ground glass screen which is viewed in on adjustable plane mirror.

All stray light is effectively screened, and there is a completely unobstructed view of the cord from above, permitting the normal use of on aximuth instrument by doy or night.

Send for our special Projector Binnocle Leoflet (NJ.57).

\section{HEATH \& COMPANY} (Incorporated with W. F. Stanlay \& Co. Led.)
NEW ELTHAM
-
LONDON, S.E.9
Phone : ELTHAM 3836
Cables : "Poleris, Souphone, London" 


\section{Decca Radar}

\section{first and foremost}

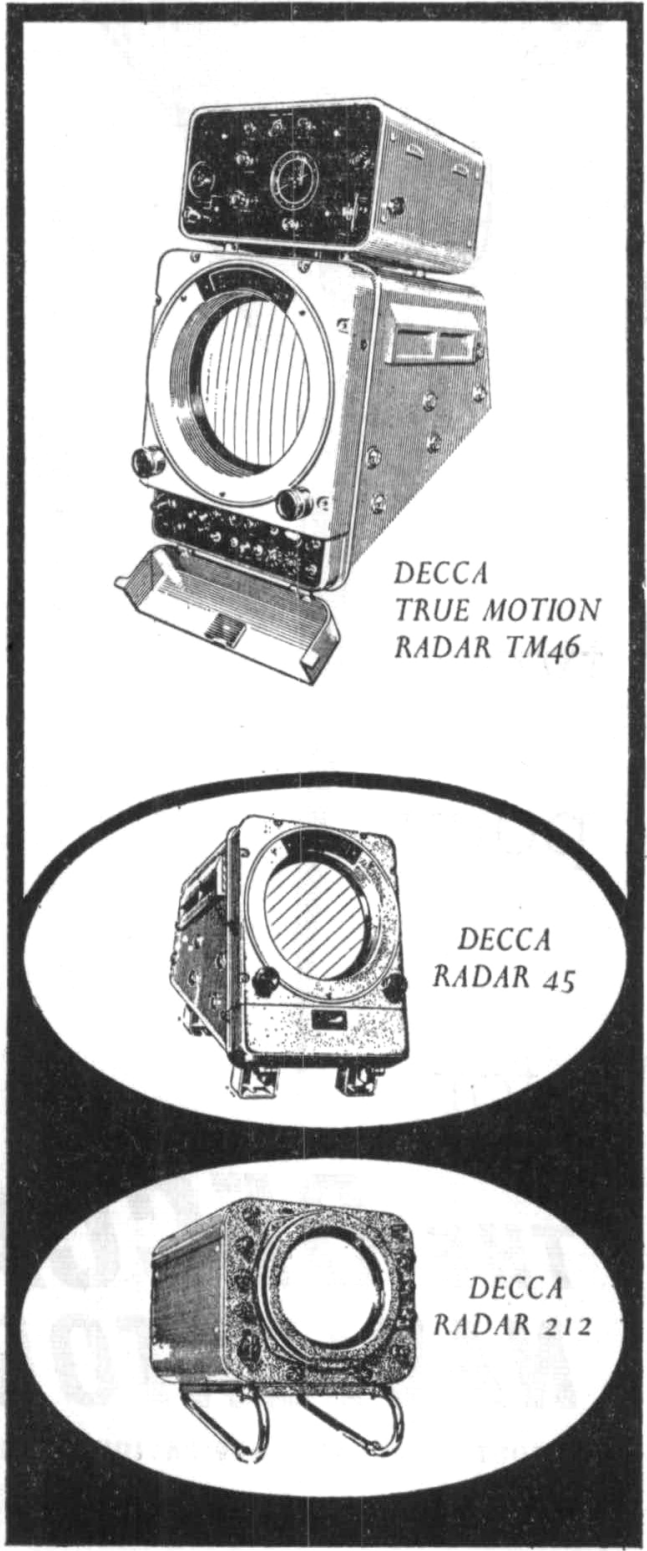

first with

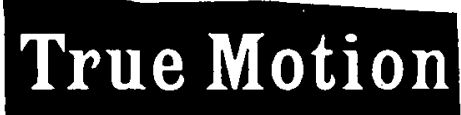

With the introduction of True Motionthe greatest single advance towards safer navigation since the inception of radar-Decea have provided the mariner with instantaneous, continuous and unambiguous information concerning the true course and speed of all largets within radar coverage. Although it was only quite recently made available, True Motion has already established itself, having received widespread acceptance by leading shipping companies throughout the world.

\section{foremost in marine radar}

Decca is already established as the leading supplier of marine radar: in the world-and is going from strength to strength. The great support enjoyed by Decca Radar is directly attributable to the long and careful programme of development and research, the results of which are embodied in the production of this series of equipment.

The available types of Decca Radar form a range which covers the completo radar needs of any type of vessel afloat. Every installation is baoked by world-wide Decca Radar service.

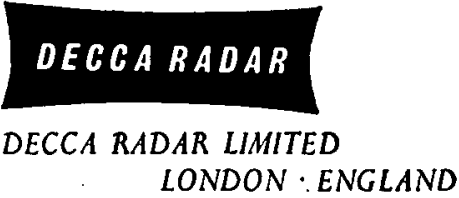




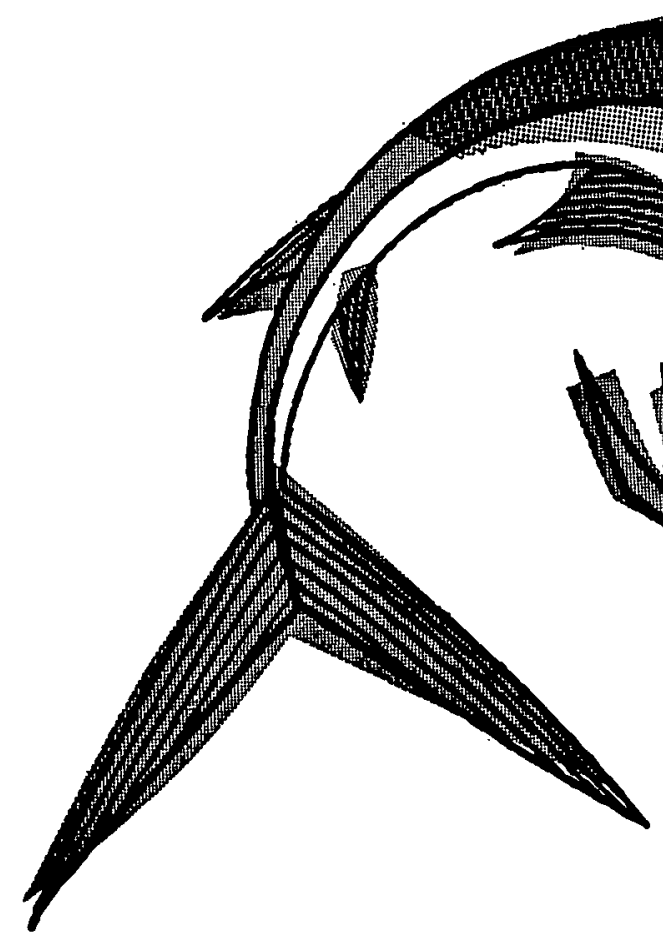

\section{sea-going types}

who see the point

...go straight for

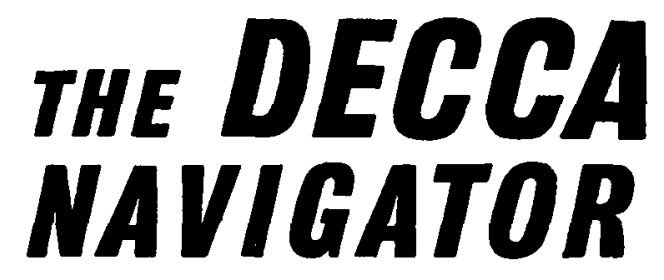

ThE WORLO'S mOST AGCURATE MAVIGATION BYSTEM

THE DECCA NAVIGATOR COMPANY LIMITED LONDON 

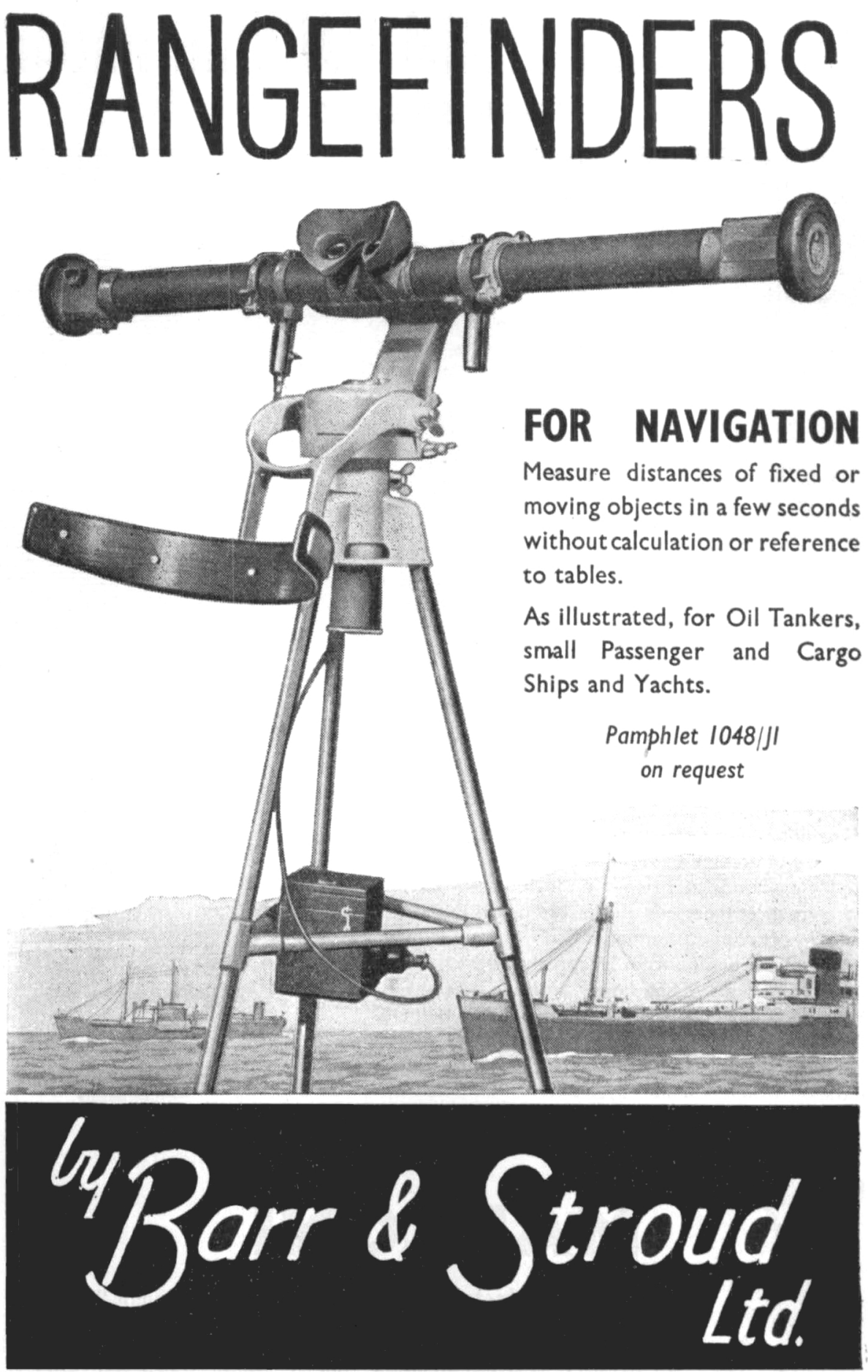

ANNIESLAND, GLASGOW, W.3

London: 15 Victoria Street, S.W.I 


\section{Marconi's $3 \mathrm{~cm}$ STORM WARNING RADAR}

\section{TYPE SNW 50}

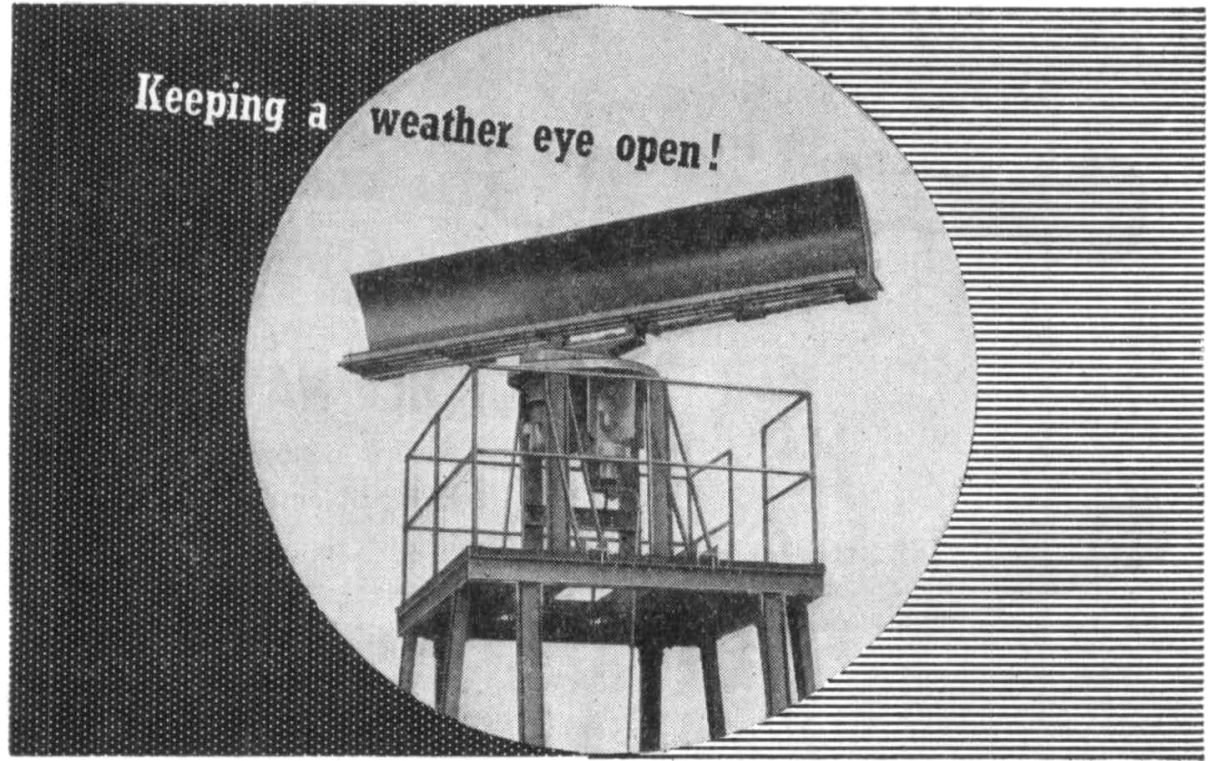

"Radar ... meteorologists' most important new instrument since they commenced to use aeroplanes"

A. C. BEMIS (Massachusetts Institute of Technology)

Marconi's Storm Detection Radar, Type SNW 50 is specially designed to present an accurate picture of storms and rainproducing clouds over ranges up to $200 \mathrm{n} . \mathrm{m}$. It can thereforc meet the needs of Meteorological Departments and Airport Authorities, particularly where it is required to derive information from inaccessible areas.

Features include:- - High Power Working, High-gain Tiltable Aerial (remote-controlled from display unit), Full OffCentring Facility (enabling any sector to be expanded to cover the whole area of the tube). Remote Displays, Static or Mobile Versions available.

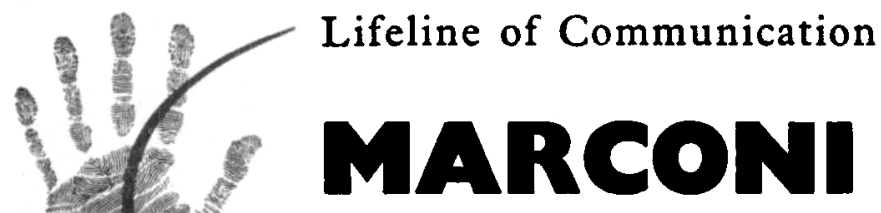

\section{Planning Installation of Military \& Civil Radar Systems}

MAACONI'S WIRELESS TELEgRAPH COMPANY LIMITED, CHELMSFORO, ESSEX 


\section{RADIO AIDS TO AIR NAVIGATION} by

J. H. H. GROVER, M.I.N.

Especially designed for airline pilots and navigators. This new volume concentrates on the performance, capabilities and operation of different types of navigational radio equipment. All important civil systems in current use in Europe and America are fully covered. Illustrated and fully indexed.

In his foreword PETER G. MASEFIELD, M.A., F.R.Ae.S., H.F. Inst.Ae.S., M.Inst.T. states:

"Flying crews/will find this book a useful compendium of basic knowledge about an essential part of their day-to-day work . . . As an 'aid' to examination work and as an 'aid' to keeping abreast with air radio today, I recommend this book to all concerned."

\section{CONTENTS INCLUDE}

Medium-frequency Systems

More Advanced MF Aids

VHF Systems

Hyperbolic Aids

Pulse Systems

Aids to Air Traffic Control

Aids to Approach and Landing

Future Aids and Trends

Charts, Documents and

Regulations

Table of Radio Aids

Formulæ and Conversion Factors

ORDER YOUR COPY OF THIS VALUABLE WORK TODAY

2/s. NET FROM ALL BOOKSELLERS

or in case of difficulty, $21 \mathrm{s.} 10 \mathrm{~d}$.

post free from

HEYWOOD AND COMPANY LTD

Book Sales Department, Tower House,

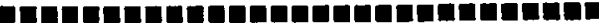

OBSERVATI ONAL ERRORS

\section{E. W. ANDERSON}

and

J. B. PARKER

This is the first of a series of monographs which the Institute is sponsoring on subjects closely. allied to navigation. Essentially it gives an elementary account of the ideas and concepts behind the statistical theory of errors. Though the examples used are primarily navigational, it is designed to appeal to all who have to deal with information or observations which are subject to error; navigation thus appears mainiy as a convenient and convincing source of illustration. The style of writing is vivid and direct, and has led to an unconventional but simple presentation that will appeal to the practical man.

JOHN MURRAY

for the Institute of Navigation

Royal 8vo. 32 pages, 25 diagrams

Price 5s. net 


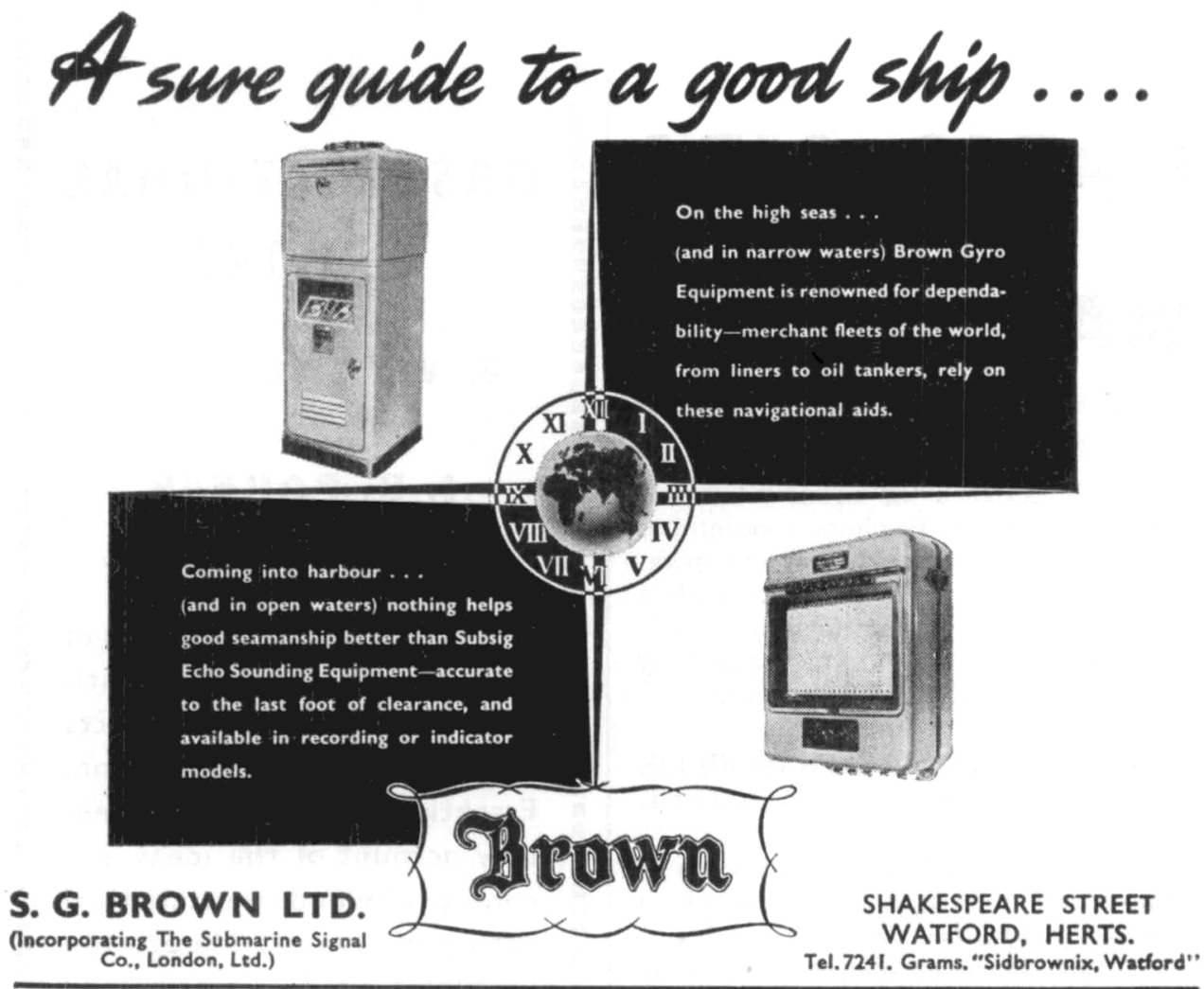

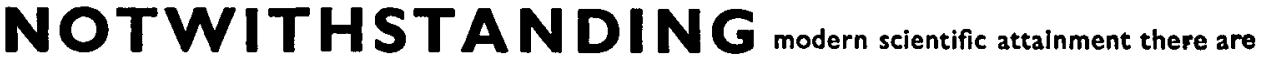

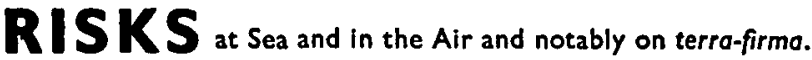

The obvious and appropriate Company for the insurance of the property and liabilities of all professional and amateur Navigators is the "Navigators and General ".

Founded in 1921 under the chairmanship of the late Admiral Sir John Franklin Parry, K.C.B., we specialize in the insurance requirements of all who are or were connected with the sea. We have added interest in their insurance problems in that the majority of our executive staff served, at one time, in the Royal or Merchant Navy. We offer impeccable security and are renowned for prompt and generous settlement of claims.

Fire Accidenses of business transacted include :

Classes of business transacted include :
Personal Effects (Ashore, Afloat, Airborne) Navigator's Indemnity (Sea and Alr) Consult your Broker or write for particulars :

THE NAVIGATORS AND GENERAL INSURANCE CO. LTD. 15/16 CULLUM STREET, LONDON, E.C.3

Phone: MANsion 2121 Grams : Avigatinsu Fen London

Deing the modernized version of the old fovourite
A MANUAL OF MODERN NAVIGATION
BROWN, SON \& FERGUSON, Ltd.
52-58, DARNLEY STRET, GLASGOW, S.I




\section{Institute Meetings}

Friday, 26 April at 5.15 p.m.

\section{METHODS OF OBTAINING A SHIP'S ASPECT AND SPEED BY RADAR}

Captain R. G. Swallow, R.N. and A. L. P. Milwright

In considering this question, which lies at the root of the collision problem, Captain Swallow of the Radio Advisory Service will first assess the value of the true-motion radar display, and Mr. Milwright of the Royal Naval Scientific Service will then describe other systems which might achieve the same purpose.

Friday, i 7 May at 5.1 5 p.m.

\section{NAVIGATION AND THE AIRLINES}

E. W. Pike

In this Paper the Navigation and Control Superintendent of British Overseas Airways Corporation examines the probable effect that increases in speed and traffic will have on route organization. He suggests that navigation may be inseparable as a subject from other aspects of air line operation.

Wednesday, Thursday, Friday, 5, 6, 7 June

\section{THE AVOIDANCE OF COLLISION BY SHIPBORNE AND AIRBORNE MEANS}

A three-day joint meeting of the Institute, the Institut Français de Navigation and the Auschuss für Funkortung. Details of the programme have been announced separately. There will be a registration fee of $\mathcal{E}_{1}$.

Friday, 21 June

\section{THE ACCURACY OF ASTRONOMICAL OBSERVATIONS AT SEA \\ D. H. Sadler, O.B.E.}

Mr. Sadler, as Chairman, will present the report of the Institute's Working Party set up in 1951 to obtain and collate information on the accuracy of astronomical observations obtained under normal conditions at sea.

There will be tea at $4.3^{\circ}$ p.m., before all meetings except during the three-day Conference. 


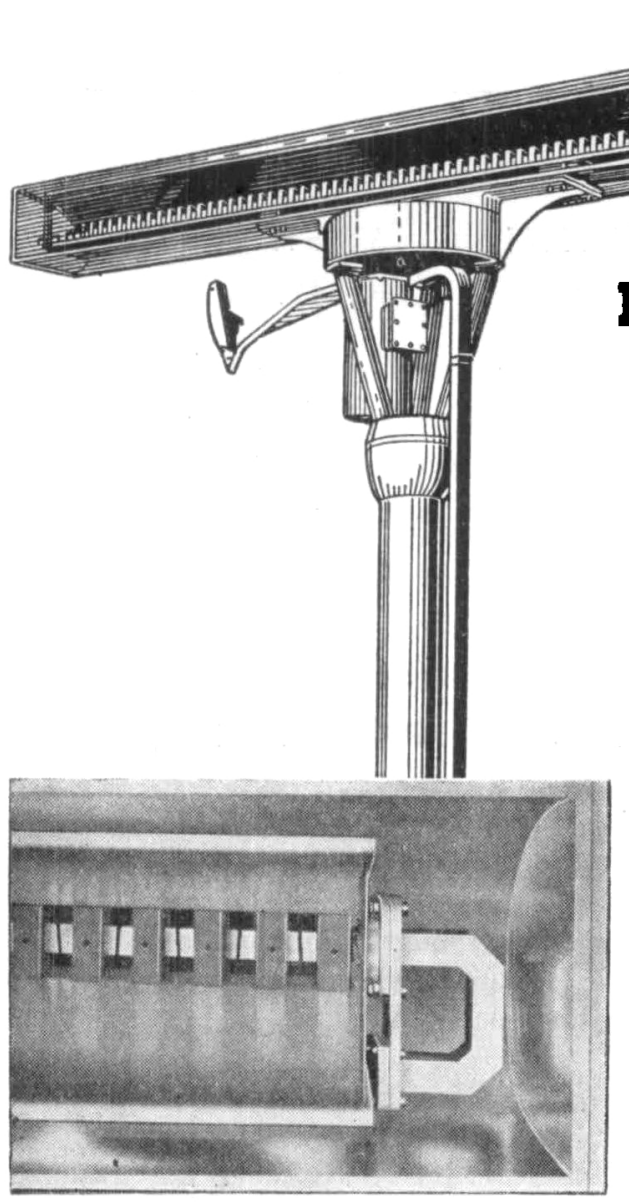

Close-up of slotted waveguide radiator showing end feed.

\section{$\star$ LOW COST}

\section{$\star$ HIGH PERForMaNGE}

\section{$\star$ GOMPAGT AND}

\section{LIGHTWEIGHT UNITS}

\section{$\mathrm{NEW}$ STP RADAR SCANNAR}

\section{Eliminates \\ Side-Lobe Echoes}

Kelvin Hughes Type I4 Marine Radar represents an entirely new approach to the design and production of ship-borne radar. A striking feature of this modern equipment is the slotted waveguide Scanner. This affords greatly improved radiation characteristics and eliminates side-lobe echoes in a Unit of very low weight and wind resistance.

These are the Technical Details:

The Aerial section of the assembly can be described as a non-resonant end fed slotted waveguide linear array, the horizontal aperture being $183 \mathrm{~cm}$. long. It radiates horizontally polarised waves, the horizontal beam width to half power points being $1.3^{\circ}$ and the vertical beam width to half power points being $27^{\circ}$.

The aerial consists of a length of waveguide having inclined slots cut in the narrow face. Slot separation, angle of inclination, and depth of cut are carefully chosen by design to give the required band width, beam width, and other radiation characteristics. The waveguide is mounted in the throat of a horn, the vertical aperture of which governs the vertical beam width. Waveguide and horn are assembled in a sealed case of toughened perspex, and the Unit is designed for clockwise rotation at a speed of 20 r.p.m.

\section{(2KHA MARINE RADAR Type 14}


A JoInt meeting of the Institute with the French Institute of Navigation and the Auschuss fuir Funkortung, to be held at the Royal Geographical Society on 5, 6, 7 June. There will be a registration fee of $f_{1}$ for the three-day conference and the papers will be available to those attending for an extra charge of ios.

\section{i. The Mathematics of Collision Avoidance at Sea}

D. H. SADLER, O.B.E.

\section{Collision Situations at Sea in Good and Poor Visibility}

CAPTAIN F. J. WYLIE, K.N., with further contributions from

(a) DR.F.W. MARIENFELD

(b) COMMANDANT L. LEMOINE-KARMOK

\section{Radar Mancuvring at Sea and the Collision Regulations}

P. Hug ON, with further contributions from

(a) CAPTAIN H. D. HARRIES

(b) Captain R. G. SWALLOW, R,N.

\section{Electronic Solutions to the Collision Problem at Sea}

Dr. H. C. Freiesleben and Captain S. Schnigelsbirg

(a) The Use of Port Radar for Marine Traffic Control

G. WIEDEMANN, and contributions on 4 by

(b) A. L. P. MILWRIGHT

(c) CAPTAIN G. CREPET

5. The Statistical Probability of Collisions in the Air

DR. E. ROSSGER, with further contributions from

(a) J.B. PARKER

(b) GENERAL DE L'AIR SARAULT

6. The Problems of Controlling Air Traffic from the Ground D. O. FRASER

7. Electronic Methods of Avoiding Collisions in the Air

COLONEL P. GAUDILlERE, with further contributions from

(a) J.K. E. KAR WATH

(b) R. BUTLER

8. Some Physiological Aspects of Collision Avoidance in the Air E. R. M. DUCKOS, A. R. MISSENARD and G.F.J. PERDRIEL

9. Conclusions of the Conference

(a) CAPTIN F. J. WYLIE, R.N.

(b) WING COMMANDBR E. W. ANDIBSON 


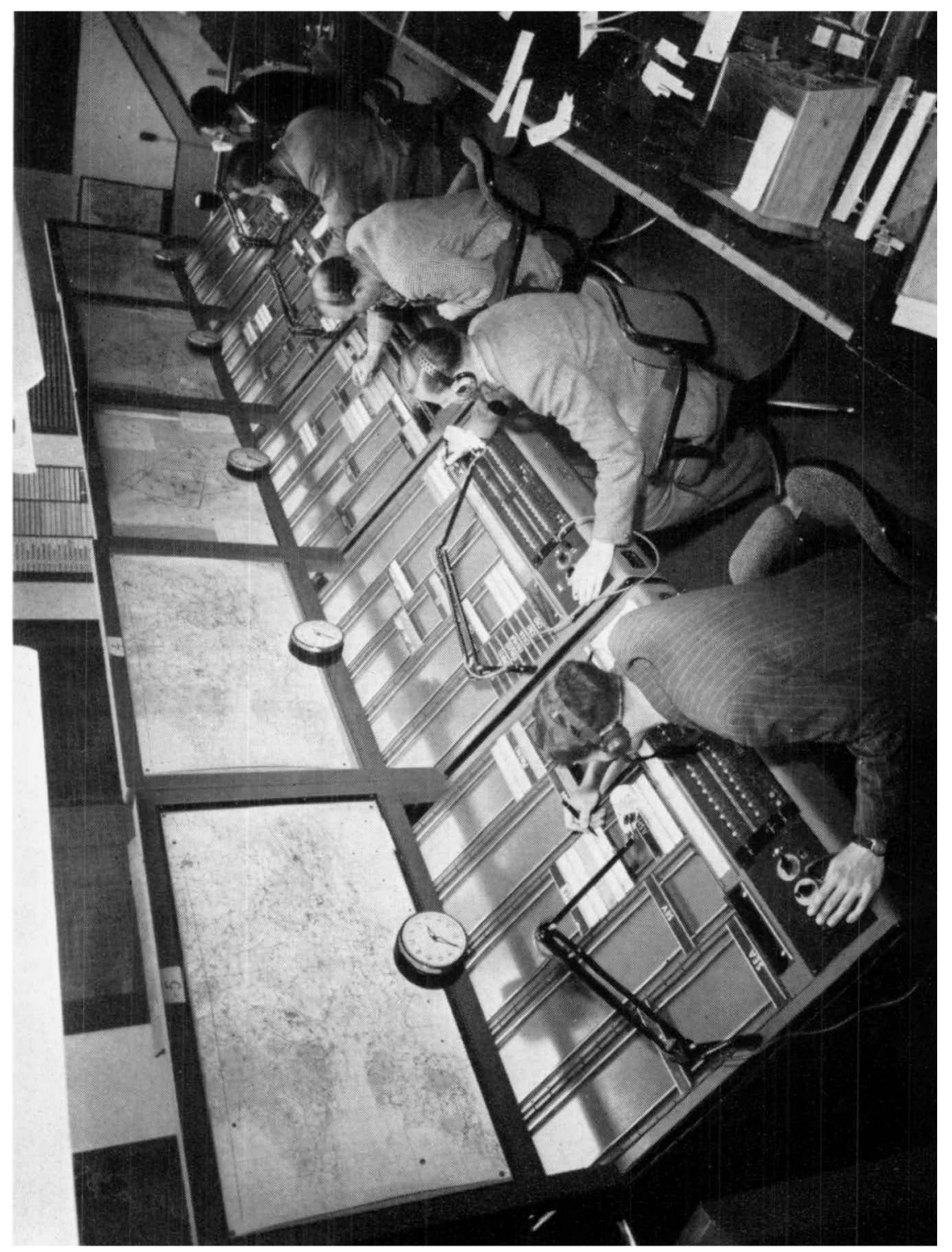

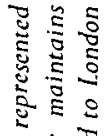

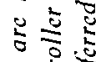

ป ถ

\&

स.

这客

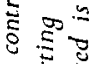

ล

ลั จั

$3 \sin ^{2}$

鸟产

동

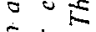

过

ปั

$5 \stackrel{\Xi}{\Xi}$

$\div \div$

응

के है

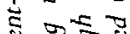

范范

के

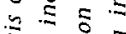

ป气

ऽ

ป气ำ

잉 2

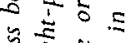

氞志芒

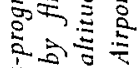

$\stackrel{5}{=}$ 